\title{
Kesadaran mahasiswa terhadap etika berbahasa
}

\author{
Grenada Tri Kardiana, Mita Nur Zahwa, Nurmalita Istifayza, Vina Aprilia, Windi Trisna \\ Devi, Devi Melati Sari, Ananda Dwitha Yuniar*
}

Universitas Negeri Malang, Jl. Semarang No. 5 Malang, Jawa Timur, Indonesia

*Penulis korespondensi, Surel: ananda.dwitha.fis@um.ac.id

Paper received: 01-05-2021; revised: 15-05-2021; accepted: 30-05-2021

\begin{abstract}
Modernization also causes a shift in interaction patterns and changes in values in society. There are still many people who do not have ethics in the campus environment, such as speaking impolitely with peers or with elders. This research was conducted to find out how to ethically speak student language to lecturers in the Sociology Department. This Research uses qualitative research method with a descriptive approach. This data collection technique is done by means of interviews. The informants of this study were lecturers of the Department of Sociology, Faculty of Social Sciences based on the criteria. The criteria used are different ages, namely senior lecturers and junior lecturers. In addition, informants were also obtained from active sociology students and came from different generations. The result of this study is that one of the factors that influence the language ethics of students is the difference of age between students and lecturers that not too far, so that students think of lecturers as their own friends, which makes them free to speak according to their wishes without thinking about who the interlocutor is and the solution for handling bad ethics is by holding activities that explain the importance of good ethics at campus since new students are in the campus environment.
\end{abstract}

Keywords: language ethics; students; politeness

\begin{abstract}
Abstrak
Modernisasi juga menimbulkan pergeseran pola interaksi dan berubahnya nilai-nilai dalam masyarakat. Masih banyak manusia yang tidak ber-etika di lingkungan kampus seperti cara berbicara yang kurang sopan baik dengan teman sebaya ataupun dengan yang lebih tua. Penelitian ini dilakukan untuk mengetahui cara beretika dalam berbahasa mahasiswa kepada dosen yang ada di Jurusan Sosiologi. Di dalam penelitian ini menggunakan metode penelitian kualitatif dengan pendekatan deskriptif. Teknik pengumpulan data ini dilakukan dengan cara wawancara. Informan penelitian ini adalah dosen jurusan Sosiologi Fakultas Ilmu Sosial dengan berdasarkan kriteria. Kriteria yang digunakan adalah umur yang berbeda yakni dosen senior dan dosen junior. Selain itu, informan juga didapatkan dari beberapa mahasiswa aktif dan berasal dari berbeda-beda angkatan. Hasil dari penelitian ini yaitu salah satu faktor yang mempengaruhi etika berbahasa mahasiswa adalah adanya perbedaan usia yang tidak terlalu jauh antara mahasiswa dengan dosen, sehingga para mahasiswa menganggap dosen seperti temannya sendiri yang membuat mereka bebas berbahasa sesuai dengan kemauannya tanpa memikirkan siapa lawan bicaranya dan solusi untuk menangani etika yang kurang baik adalah dengan mengadakan kegiatan yang menjelaskan pentingnya beretika yang baik di kampus sejak mahasiswa baru berada di lingkungan kampus.
\end{abstract}

Kata kunci: etika berbahasa; mahasiswa; kesantunan

\section{Pendahuluan}

Modernisasi membawa perubahan yang lebih maju bagi kehidupan, namun modernisasi juga memberi dampak negatif yang mempengaruhi kehidupan (Vesiano, 2015). Modernisasi juga menimbulkan pergeseran pola interaksi dan berubahnya nilai-nilai dalam masyarakat (Asia, 2008). Masih banyak manusia yang tidak ber-etika di lingkungan kampus seperti cara berbicara yang kurang sopan baik dengan teman sebaya ataupun dengan yang lebih tua. salah 
satu bentuk modernisasi masa kini adalah berkembangnya TIK, dalam (Diana,2016) TIK adalah seperangkat sumber daya dan peralatan teknologi yang digunakan untuk berkomunikasi, menciptakan, menyimpan, dan mengelola informasi. Peralatan teknologi dimaksud antara lain komputer, internet, teknologi penyiaran (radio dan televisi), dan telepon (HP). Dengan demikian, di era saat ini HP merupakan salah satu media seseorang untuk bisa berkomunikasi, salah satunya dengan dosen yang ada di kampus.

Tak sedikit jumlah mahasiswa yang memiliki sikap tidak beretika dalam berkomunikasi dengan para dosennya. Dalam Nailiya Nikmah, Noor R. Rahwani, \& Fitriani (2018) Aspek etika termasuk aspek penting yang menjadi bagian setiap profesi. Isu - isu etika ini muncul dalam semua jenis komunikasi termasuk komunikasi interpersonal, komunikasi politik, komunikasi organisasi, iklan dan media berita. Etika menimbulkan keterampilan intelektual, yaitu keterampilan berargumentasi secara rasional dan kritis. Dalam kehidupan bermasyarakat semakin banyak orang yang tidak mengenal etika dalam berkomunikasi. Hal ini dapat kita buktikan dalam laman liputan6.com pada tanggal 07 September 2020 oleh (Marenda, 2020) diberitakan bahwa terdapat beberapa contoh teks WA yang dikirimkan mahasiswa kepada Dosen dengan bahasa yang tidak sopan dan membuat geleng kepala. Etika sendiri berasal dari kesadaran manusia terhadap nilai dan aturan yang ada. Sejak dari dulu etika yang berupa aturan sudah ada, namun penerapan di lingkungan sekitar masih kurang. Contoh etika terhadap nilai misalnya adalah mengantri dengan teratur, makan menggunakan tangan kanan, dan minum tidak boleh berdiri. Jika hal itu dilakukan dengan sebaliknya, maka orang tersebut akan dikatakan tidak beretika. Contoh dari etika aturan yang sudah diterapkan misalnya cara berpakaian di kampus yang harus sopan, jika warga kampus tidak memakai pakaian dengan sopan, maka ia akan dianggap tidak mengikuti peraturan dan tidak beretika. Contoh lainnya adalah mahasiswa harus berbicara yang sopan pada dosen baik secara langsung ataupun melalui media sosial, jika mahasiswa tidak berbicara secara sopan, maka mahasiswa tersebut dianggap tidak beretika.

Berbeda dengan etika dalam nilai, etika dalam peraturan sudah diterapkan di beberapa kampus salah satunya adalah Universitas Negeri Malang. Peraturan di kampus diterapkan untuk membiasakan mahasiswa untuk selalu beretika. Etika perilaku dan etika berbahasa sangat dibutuhkan karena hal tersebut mencerminkan jati diri. Perilaku merupakan tindakan seseorang dalam melakukan sesuatu. Dalam (Wartoyo, 2019) Komunikasi dalam revolusi 4.0 mengalami perubahan signifikan antara perilaku dan bahasa yang memunculkan budaya yang seringkali tidak sesuai dengan identitas akademis yang mengedepankan etika dan sopan santun, maka dalam dunia akademis perlu adanya peraturan dan contoh dalam berkomunikasi antara dosen dan mahasiswa agar konsep pendidikan, identitas, dan karakter bangsa Indonesia tetap terjaga sopan santun dan serta mengedepankan filosofis bangsa sebagai generasi penerus dalam menghadapi zaman milenial sehingga tidak terjebak pada sisi negatif dalam digitalisasi dalam dunia akademis.Tujuan peneliti melakukan penelitian ini adalah untuk mengetahui etika dalam berbahasa pada mahasiswa jurusan Sosiologi di Universitas Negeri Malang.

\section{Metode}

Penelitian ini dilakukan untuk mengetahui cara beretika dalam berbahasa mahasiswa kepada dosen yang ada di Jurusan Sosiologi. Penelitian ini berada di Universitas Negeri Malang Fakultas Ilmu Sosial pada Jurusan Sosiologi, dan penelitian ini dilaksanakan pada bulan November 2019. Di dalam penelitian ini menggunakan metode penelitian kualitatif dengan 
pendekatan deskriptif (Creswell, 2010) menjelaskan bahwa penelitian kualitatif merupakan metode untuk mengeksplorasi dan memahami makna yang oleh sejumlah individu atau sekelompok orang dianggap berasal dari masalah sosial atau kemanusiaan. Seperti penjelasan Moleong (2004) penelitian kualitatif menggunakan pengamatan, wawancara atau penelaahan dokumen. Teknik pengumpulan data ini dilakukan dengan cara wawancara.

Objek penelitian ini adalah 4 dosen jurusan Sosiologi Fakultas Ilmu Sosial dengan berdasarkan kriteria dari seorang dosen tersebut. Kriteria yang digunakan adalah umur yang berbeda yakni dosen senior dan dosen junior, dengan berdasarkan pada pengalaman dosen senior yang lebih banyak dalam menghadapi mahasiswanya. Sehingga dirasa bahwa dosen senior lebih banyak berpengalaman dalam menghadapi etika mahasiswa yang beragam dan yang sudah lama. Sedangkan, dosen junior dijadikan sebagai narasumber kedua karena pautan umur antara dosen dengan mahasiswa tidak jauh berbeda. Sehingga pengambilan 2 narasumber dengan pautan umur yang berbeda dirasa akan memunculkan 2 perspektif yang berbeda terhadap etika mahasiswa terhadap dosen.

Narasumber yang lainnya adalah 4 mahasiswa dari 4 angkatan yang ada di Fakultas Ilmu Sosial yang masih aktif di kampus. Pengambilan narasumber ini dikarenakan adanya perbedaan angkatan yang membuat setiap angkatan dianggap memiliki etika yang berbedabeda ketika menghadapi dosen yang terpaut umur lebih dekat dengannya ataupun yang lebih tua. Selain itu perbedaan angkatan ini juga sebagai acuan untuk mengukur tingkat kepemilikan etika yang tinggi seseorang dari tahun ke tahun yang semakin hari semakin menurun.

\section{Hasil dan Pembahasan}

Dalam penelitian ini peneliti membahas kasus mengenai Etika Berbahasa kepada Dosen di Jurusan Sosiologi Universitas Negeri Malang. Etika berbahasa yang digunakan dalam penyampaian kata kepada dosen perlu diperhatikan mahasiswa. Peneliti mewawancarai 4 (empat) dosen dan 4 (empat) mahasiswa dan memberikan pertanyaan terkait Etika Berbahasa kepada Dosen terutama berbahasa dalam menyampaikan pesan melalui media sosial atau secara langsung. Berikut uraian pembahasan dalam penelitian ini.

\subsection{Etika Berbahasa yang Baik}

Peneliti menanyakan kepada 4 (empat) dosen bagaimana etika berbahasa yang baik yang dilakukan oleh mahasiswa, jawaban semua informan beragam. 1 (satu) informan dosen sosiologi yaitu Bapak Alan Sigit Fibrianto (26 tahun) menjawab bahwa etika berbahasa yang baik dalam pengiriman pesan adalah diawali dengan salam, pengenalan mahasiswa, keperluan mahasiswa tersebut dan menanyakan apakah dosen tersebut mempunyai waktu senggang untuk keperluan tersebut dan diakhiri dengan salam. Berbeda dengan berbahasa dalam menyampaikan pesan, menurut informan tersebut beretika dalam berbahasa secara langsung adalah dengan memperhatikan tutur kata yang baik. 1 (satu) informan lain dosen sosiologi yaitu Ibu Seli Septiana Pratiwi (27 tahun) menjawab bahwa etika yang baik dalam menyampaikan pesan adalah dengan pemilihan kata-kata yang baik sedangkan untuk berbahasa secara langsung, mahasiswa harus memperhatikan intonasi kepada lawan bicara. 1(satu) informan lain dosen sosiologi yaitu Bapak Irawan (61 tahun) menjawab etika berbahasa yang baik yaitu harus paham bahwa masyarakat itu berubah termasuk etika, norma dan aturan berubah. Perubahan yang besar sekarang ini berdampak pada etika dan etika berbahasa menjadi jelas. Kandungan etika menjadi jelas dan etika berbahasa menjadi seperti 
ke teman sehingga tutur kata dalam berbahasa menjadi kurang tampak. Harus ada kesadaran dan harus ada persetujuan yang diungkapkan. 1(satu) informan lain dosen sosiologi yaitu Ibu Desy Santi Rozakiyah (29 tahun) menjawab untuk mahasiswa baru sosiologi menurutnya masih melakukan adaptasi dengan lingkungan baru dan untuk mahasiswa yang sudah lama dia begitu acuh dan tidak mau mendengarkan apa yang disampaikan oleh dosen. Mungkin mahasiswa lama menganggap bahwa dia sudah lama menjadi mahasiswa.

Sedangkan, menurut kacamata mahasiswa peneliti menanyakan etika yang baik seperti apa, informan pertama mahasiswa angkatan 2015 yaitu Dimas (22 tahun) menjawab cara yang baik untuk menghadapi dosen dalam berbicara. Informan kedua mahasiswa angkatan 2017 yaitu Venia (20 tahun) menjawab mahasiswa sosiologi sebagian belum beretika karena banyak ditemui kata-kata yang kasar baik di lingkungan fakultas maupun di lingkungan kantin. Informan ketiga mahasiswa angkatan 2018 yaitu Atus (19 tahun) menjawab belum mengetahui etika yang baik. Informan keempat mahasiswa angkatan 2019 yaitu Diah (17 tahun) menjawab menurutnya dia sudah menerapkan etika berbahasa yang baik entah itu dengan sesama teman maupun dosen dan tendik.

\subsection{Etika Berbahasa Mahasiswa Sosiologi Universitas Negeri Malang}

Selanjutnya peneliti menanyakan sudahkah mahasiswa sosiologi memiliki etika yang baik, informan pertama dosen sosiologi yaitu Bapak Alan Sigit Fibrianto (26 tahun) menjawab bahwa dari tiap angkatan memberikan kesan yang berbeda, menurutnya etika mahasiswa sekarang menurun dan mengalami pergeseran. Terbukti dari mahasiswa angkatan 2016 yang diajar oleh dosen tersebut, saat ini etika mereka sudah menurun. Akan tetapi, mahasiswa angkatan 2018 dan 2019 sudah ada peningkatan dalam hal etika terhadap dosen. Jawaban informan kedua dosen sosiologi yaitu Ibu Seli Septiana Pratiwi (27 tahun) secara keseluruhan sudah memiliki etika yang berbicara yang baik namun ada beberapa orang yang masih perlu diperbaiki cara berbicara dan sebaiknya dengan sesama mahasiswa harus tetap menjaga konteks menghormati orang lain. Jawaban informan ketiga dosen sosiologi yaitu Bapak Irawan (61 tahun) sebagai mahasiswa seharusnya bisa membedakan berbicara dengan teman, orang tua, dan dosen. Meskipun etika berubah harus tetap menjaga etika yang baik disini status dan peranan harus tampak. Jawaban informan keempat dosen sosiologi yaitu Ibu Desy Santi Rozakiyah (29 tahun) untuk mahasiswa baru masih dimaklumi karena mereka belum mengetahui secara baik bagaimana beretika dan untuk mahasiswa yang sudah lama merasa bahwa dosen tersebut tidak berbeda jauh dengannya dia sehingga dia tidak begitu memperhatikan cara berbicara.

Setelah itu peneliti menanyakan sudahkah mahasiswa itu beretika di kampus, informan pertama mahasiswa angkatan 2015 yaitu Dimas ( 22 tahun) menjawab sudah beretika kepada orang tua kadang dengan lingkungan sesama teman kadang melanggarnya. Informan kedua mahasiswa angkatan 2017 yaitu Venia (20 tahun) menjawab solusinya saling mengingatkan. Informan ketiga mahasiswa angkatan 2018 yaitu Atus (19 tahun) menjawab tidak ada solusinya karena dalam berbahasa orang memiliki hak masing-masing individu dalam berbicara, jadi terserah mereka mau menggunakan bahasa tidak baku pun yang penting sopan dan bisa dimengerti. Informan keempat mahasiswa angkatan 2019 yaitu Diah (17 tahun) menjawab sebenarnya solusinya itu kembali kepada diri sendiri, menurutnya percuma mengingatkan tetapi orang tersebut tidak ada keinginan untuk berubah. Tetapi mungkin perlu 
ada konseling ataupun pembelajaran berbasis karakter sebagai mahasiswa untuk meminimalisir mahasiswa/mahasiswi yang kurang attitude-nya dalam berbahasa.

\subsection{Menyikapi Mahasiswa yang Kurang Beretika dalam Berbahasa}

Kemudian peneliti menanyakan bagaimana cara menyikapi mahasiswa sosiologi yang kurang beretika dalam berbahasa, informan pertama dosen sosiologi yaitu Bapak Alan Sigit Fibrianto (26 tahun) menjawab caranya yaitu dengan memberikan penilaian sikap terhadap mahasiswa dan berefek pada nilai kesopanan dengan pengamatan secara langsung di dalam kelas. Informan kedua dosen sosiologi yaitu Ibu Seli Septiana Pratiwi (27 tahun) menjawab secara langsung tidak pernah mengalaminya namun mahasiswa kadang tidak sadar berbicara dengan sesama mahasiswa namun dengan bahasa yang kurang pantas di depan dosennya. Informan ketiga dosen sosiologi yaitu Bapak Irawan (61 tahun) menjawab masih ada mahasiswa sosiologi yang kurang beretika baik. Masih ada mahasiswa yang menyebut "anda" kepada dosen. Solusinya dinasehati dan apabila tidak berubah maka dibiarkan. Informan keempat dosen sosiologi yaitu Ibu Desy Santi Rozakiyah (29 tahun) menjawab selalu mengingatkan ketika di akhir jam perkuliahan kepada mahasiswa yang sudah lama bahwa harus mencerminkan etika yang baik dengan adik tingkatnya dan untuk mahasiswa baru selalu menegur secara langsung dengan mahasiswa baru tersebut.

\subsection{Solusi Menyikapi Mahasiswa yang Kurang Beretika dalam Berbahasa}

Setelah itu peneliti menanyakan bagaimana solusi menyikapi mahasiswa sosiologi yang kurang beretika dalam berbahasa, informan pertama dosen sosiologi yaitu Bapak Alan Sigit Fibrianto (26 tahun) menjawab dengan adanya kegiatan pengenalan dari pihak fakultas kepada mahasiswa baru sejak awal tentang bagaimana cara beretika yang baik dan dengan adanya himpunan mahasiswa diharapkan mampu menjadi wadah untuk mengatasi masalah mahasiswa itu sendiri. Serta dari diri mahasiswa sendirilah yang mampu untuk merubah etika di lingkungannya. Informan kedua dosen sosiologi yaitu Ibu Seli Septiana Pratiwi (27 tahun) menjawab hal itu dimulai dari diri personalnya sendiri dan solusinya yaitu dengan menegur dan menasehati mahasiswa agar bertutur kata lebih baik lagi ketika berbicara. Informan ketiga dosen sosiologi yaitu Bapak Irawan (61 tahun) menjawab solusi untuk mahasiswa kurang etika sebagai seorang dosen antropologi mengajarkan nilai, norma, dan aturan dalam sistem budaya yang dikaitkan dengan status dan peranan. Etika dimanapun dijunjung tinggi. Informan keempat dosen sosiologi yaitu Ibu Desy Santi Rozakiyah (29 tahun) menjawab secara langsung tidak pernah mengalaminya dari mahasiswa baru namun kebanyakan mahasiswa yang sudah semester akhir banyak meremehkan dosen muda tapi dengan dosen yang sudah lama mahasiswa lama lebih menjaga sikapnya.

Adapun jawaban dari mahasiswa untuk informan pertama adalah mahasiswa angkatan 2015 yaitu Dimas (22 tahun) menjawab ketika dia memiliki teman dengan attitude yang kurang baik dalam berbahasa khususnya pertama mengingatkan bahwa berbahasa dia kurang baik dan kurang sopan, jika belum sadar diingatkan lagi kebiasaan/budaya disini berbeda dengan kebiasaan/budayanya di rumah asalnya. Informan kedua mahasiswa angkatan 2017 yaitu Venia (20 tahun) menjawab mengingatkan saja, jika mereka masih tetap saja beretika tidak baik berarti harus mengajarkan bahasa yang benar tapi jika sudah tidak bisa maka dibiarkan saja. Informan ketiga mahasiswa angkatan 2018 yaitu Atus (19 tahun) menjawab sikap ke dosen hampir beretika, contohnya di dalam kelas ada yang keceplosan dalam 
berbicara. Informan keempat mahasiswa angkatan 2019 yaitu Diah (17 tahun) menjawab tergantung pada individu sendiri dan ketika melihat orang kurang beretika hanya memendamnya saja. Faktor yang membuat orang tidak beretika yaitu faktor budaya yang berbeda dan emosional.

\subsection{Pentingkah Pembelajaran secara Khusus mengenai Etika}

Terakhir peneliti menanyakan apakah pembelajaran etika penting untuk diajarkan ketika pembelajaran di kelas, Jawaban informan pertama dosen sosiologi yaitu Bapak Alan Sigit Fibrianto (26 tahun) menurutnya pembelajaran etika tidak perlu diadakan dalam suatu mata kuliah itu tergantung individu masing-masing dan setiap mata kuliah selalu disisipkan. Informan kedua dosen sosiologi yaitu Ibu Seli Septiana Pratiwi (27 tahun) menjawab penting diterapkan karena etika merupakan kebiasaan yang dibangun dan setiap mata kuliah memiliki penilaian sikap dengan penerapan yang maksimal maka akan terbentuk karakter mahasiswa itu sendiri. Informan ketiga dosen sosiologi yaitu Bapak Irawan (61 tahun) menjawab etika selalu disisipkan di beberapa mata kuliah yang cocok. Informan keempat dosen sosiologi yaitu Ibu Desy Santi Rozakiyah (29 tahun) menjawab itu tidak begitu penting dan menurutnya sejak kecil sudah ditanamkan tata krama yang didasari dari lingkungan keluarga. Ketika anak itu sejak kecil ditanamkan etika maka ia akan mengingat etika tersebut namun ketika etika baru mulai ditanamkan itu sudah terlambat dan menganggap itu hal tidak penting.

\subsection{Pemahaman Mahasiswa mengenai Etika}

Peneliti menanyakan kepada 4 (empat) mahasiswa apa yang diketahui tentang etika, informan pertama mahasiswa angkatan 2015 yaitu Dimas (22 tahun) menjawab Etika merupakan perwujudan norma. Informan kedua mahasiswa angkatan 2017 yaitu Venia (20 tahun) menjawab menggunakan Bahasa Indonesia yang bisa dipahami oleh semua orang, tidak harus menggunakan Bahasa Indonesia yang baku tetapi tetap menjaga tutur kata yang sopan dan bisa dimengerti. Informan ketiga mahasiswa angkatan 2018 yaitu Atus (19 tahun) menjawab menurutnya sebagai mahasiswa yang tentunya harus memiliki etika menyesuaikan dengan peraturan dan lingkungan sekitarnya. Karena kebanyakan mahasiswa pendatang dari luar Malang yang memiliki kebiasaan/budaya yang berbeda-beda. Dengan perbedaan itu sebagai mahasiswa kita perlu menyesuaikan sikap kita dengan kebiasaan maupun lingkungan yang ada di sekitar kita. Bukan berarti jika berada dilingkungan yang tidak baik harus menyesuaikan tidak baik pula. Selain itu, kita perlu menjunjung tinggi sopan santun kepada siapapun. Informan keempat menjawab mahasiswa angkatan 2019 yaitu Diah (17 tahun) seperti cara bersikap, sopan santun, dan berbahasa cara kita berbicara dengan dosen.

Berdasarkan hasil yang peneliti peroleh etika yang digambarkan oleh mahasiswa terhadap dosen sangat beragam. Hal ini dapat dilihat dari sikap mahasiswa yang menyalahartikan suatu etika yang dianggapnya baik. Mahasiswa yang menyalahartikan etika yang baik berdasarkan pandangannya dapat disebabkan karena adanya pandangan bahwa perlakuan yang harus dilakukan mahasiswa terhadap dosen muda dan dosen tua tentu berbeda. Hal ini disebabkan karena perbedaan usia antara dosen muda dan mahasiswa yang berjarak tidak terlalu jauh. Mahasiswa sering menganggap bahwa yang lebih patut untuk diberikan tata perlakuan yang khusus hanya kepada dosen yang tua karena dosen tua dianggap memiliki kedudukan yang lebih tinggi serta adanya batasan kedekatan antara mahasiswa dengan dosen tua. Selain itu, perlakuan mahasiswa terhadap dosen tua juga seringkali masih 
dianggap tidak sesuai dengan etika yang seharusnya. Berbeda dengan perlakuan mahasiswa kepada dosen tua, mahasiswa akan cenderung menyepelekan posisi dosen muda. Selain karena usia yang tidak terpaut jauh, mahasiswa menganggap tidak adanya batasan kedekatan dengan dosen muda karena mereka lahir pada generasi yang sama. Etika yang seharusnya dilakukan oleh mahasiswa yaitu dengan tidak membeda-bedakan tata cara memperlakukan baik dosen muda maupun dosen tua. Dosen muda maupun dosen tua memiliki kedudukan yang sama, yaitu sama-sama harus diperlakukan baik sesuai dengan etika dan kesantunan yang berlaku terutama di lingkungan kampus. Etika berbahasa yang dianggap memenuhi kriteria baik yaitu dengan menggunakan bahasa yang santun dan baku, tidak bernada lebih tinggi, dan menggunakan bahasa yang dapat dimengerti. Sedangkan, hasil penelitian yang diteliti oleh Diana (2016), menunjukkan bahwa seseorang memiliki sikap yang tidak santun dalam berkomunikasi disebabkan oleh beberapa hal yaitu: 1) Kurangnya perbendaharaan bahasa Indonesia yang baku, 2) Terbiasa di lingkungan dan kebiasaan tersebut dipertahankan tanpa perubahan, 3) Tidak bisa membedakan tata bahasa yang baik, 4) Pengaruh dari bahasa gaul, 5) Tidak bisa membedakan mana pesan untuk orang tua, sebaya dan anak-anak. Beberapa hal tersebut merupakan hal-hal yang dapat menyebabkan kesalahan dalam berkomunikasi baik bahasa lisan atau bahasa tulisan.

Jika dilihat dari segi konsep nilai dan norma, etika yang terjadi pada mahasiswa berkaitan erat dengan custom (adat istiadat) hal ini dapat dilihat dari adanya mahasiswa yang terbiasa dengan budaya yang ada di daerahnya masing-masing. Seperti kebudayaan yang terjadi di wilayah Jawa. Wilayah Jawa sangat terkenal dengan sikap sopan santun dan unggah ungguhnya, dalam segi bahasa, masyarakat Jawa terkesan sangat halus dan santun. Hal ini akan memicu mahasiswa terbawa untuk selalu berbahasa dan bertutur kata menurut kebudayaan yang telah tertanam dalam dirinya. Mengingat, bahasa yang ada di daerah Jawa juga dibagi menjadi 3 kategori, yakni ngoko, krama alus, dan krama inggil. Ketika masyarakat di luar Jawa beranggapan bahwa krama alus merupakan bahasa Jawa yang sudah dapat dikatakan halus, ternyata masih terdapat bahasa yang lebih halus diatasnya yaitu krama inggil. Krama inggil biasanya digunakan oleh golongan muda untuk bertutur kata kepada orang Jawa yang tergolong sepuh. Ketika seseorang telah menanamkan adat istiadat di manapun ia berada, mereka akan terbiasa dengan adat istiadat yang mereka anut (folkways). Begitu juga dengan norma, etika berbahasa juga mengandung nilai dan norma seperti norma kesopanan dan norma agama. Apabila mahasiswa berbahasa sesuai dengan etika yang berlaku, maka dapat dikatakan mahasiswa tersebut telah menerapkan norma kesopanan tersebut. Norma yang dijadikan sebagai pedoman mahasiswa dalam segi etika berbahasa sangat diperlukan untuk mengontrol diri agar tidak bertutur kata yang semena-mena dan melanggar nilai dan norma kesopanan.

Etika berasal dari kesadaran manusia terhadap nilai, norma, dan aturan yang ada. Etika sendiri sudah ada sejak dahulu. Istilah etik yang sepadan dengan istilah moral, tentunya mengarah pada baik atau buruk, benar atau salah, bahkan munculnya penyimpangan yang disebabkan karena minimnya pemahaman individu mengenai etika yang menjadi pondasi penting (Hudiarini, 2017). Dengan begitu, segala hal yang dilakukan individu tentunya dilandasi oleh etika dimana etika lah yang menuntun individu dalam melakukan suatu hal. Namun, dalam penerapannya di lingkungan sekitar masih ada beberapa individu yang beretika kurang baik. Contohnya, etika berbahasa yang dilakukan mahasiswa kepada dosen, baik saat menyampaikan pesan melalui media sosial ataupun berbicara secara langsung. Etika berbahasa yang dilakukan mahasiswa saat ini sudah mulai menurun dan mengalami 
pergeseran. Mereka berbicara pada dosen sama halnya berbicara dengan teman sendiri sehingga tutur kata dalam berbahasa menjadi kurang tampak. Meskipun etika sudah berubah, namun tetap harus menjaga etika yang baik agar status dan peranan tetap tampak. Solusi yang diberikan informan untuk mengatasi mahasiswa yang kurang beretika adalah melalui kegiatan pengenalan dari pihak fakultas kepada mahasiswa baru sejak awal tentang bagaimana cara beretika yang baik, melalui himpunan mahasiswa yang merupakan wadah pemecahan masalah para mahasiswa, serta melalui materi yang diajarkan dosen antropologi tentang nilai,norma, dan aturan dalam sistem budaya yang dikaitkan dengan status dan peranan. Sehingga, pembelajaran etika sangat penting diajarkan untuk membentuk karakter mahasiswa itu sendiri. Menurut analisa peneliti, etika berbahasa sangat penting untuk diajarkan sejak dini. Hal tersebut akan membentuk karakter yang kuat untuk seorang individu. Serta, akan menjadi pedoman seorang individu untuk menghadapi pergeseran norma dan aturan yang akan terjadi.

\section{Simpulan}

Berdasarkan hasil dan pembahasan, peneliti dapat menyimpulkan Faktor-faktor yang mempengaruhi etika berbahasa mahasiswa adalah: 1) Adanya perbedaan usia yang tidak terlalu jauh antara mahasiswa dengan dosen, sehingga para mahasiswa menganggap dosen seperti temannya sendiri yang membuat mereka bebas berbahasa sesuai dengan kemauannya tanpa memikirkan siapa lawan bicaranya. 2) Etika mahasiswa dipengaruhi oleh faktor budaya yang didapat dari sejak dini dan diterapkan dimanapun dia berada termasuk wilayah kampus, sehingga secara tidak sengaja mahasiswa tersebut memiliki etika yang sudah tertanam di dalam dirinya. 3) Kesadaran diri dari mahasiswa itu sendiri yang menentukan apakah dia ingin beretika baik atau tidak.

Solusi untuk memperbaiki etika yang kurang baik pada mahasiswa yaitu: 1) Kesadaran dari diri sendiri merupakan kunci yang sangat penting untuk melakukan sebuah tindakan, seperti halnya beretika bahasa yang baik saling mengingatkan antar individu. Apabila seorang individu dilihat kurang baik dalam hal etika berbahasa, sebaiknya kita sebagai makhluk sosial saling mengingatkan agar individu tersebut membiasakan beretika yang baik. 2) Faktor yang selanjutnya yaitu mengadakan kegiatan yang menjelaskan pentingnya beretika yang baik di kampus sejak mahasiswa baru berada di lingkungan kampus. Seperti, yang dilakukan oleh jurusan sosiologi mengadakan kegiatan pengenalan budaya kampus dalam lingkungan sosiologi yang bernama elklaren.

Tata cara etika berbahasa mahasiswa terhadap dosen yang baik dan benar ketika bertatap muka (secara langsung) dan melalui media sosial (secara tidak langsung) yaitu ketika mahasiswa akan bertemu dan tidak sengaja bertemu dengan dosen maka hal pertama yang harus dilakukan oleh mahasiswa untuk mencerminkan etika yang baik yaitu dengan mengucapkan salam terlebih dahulu atau tersenyum kepada dosen baik yang seumuran maupun yang lebih tua dari mahasiswa tersebut. Ketika mahasiswa ingin menghubungi dosen dengan tujuan tertentu melalui pesan singkat sebaiknya mahasiswa menerapkan tata cara etika mengirim pesan yang baik kepada dosen diantaranya: 1) Mengucapkan salam terlebih dahulu. 2) Memberi tahu identitas diri berupa nama, program studi, dan tahun angkatan. 3) Mengucapkan maaf (jika pesan dianggap mengganggu waktu dosen yang ingin dihubungi) dan memberi tahu tujuan yang jelas dengan bahasa yang baku dan sopan. 4) Diakhiri dengan terima kasih dan salam. Adapun ketentuan waktu untuk mengirim pesan kepada dosen yaitu dibatasi sampai jam 9 malam. 


\section{Daftar Rujukan}

Aminah, S. (2017). Prinsip Kerjasama dan Kesantunan Bahasa dalam Wacana Chatting Antara Mahasiswa dan Dosen Jurusan Bahasa Indonesia Melalui Smartphone (Sosiolinguistik dan Pragmatik) (Doctoral dissertation, Tesis tidak diterbitkan. Malang: Pascasarjana Universitas Islam).

Asia, N. (2009). Hubungan antara harga diri dan asertivitas dengan perilaku prososial remaja (Doctoral dissertation, Universitas Muhammadiyah Surakarta).

Budiwati, T. R. (2017). Kesantunan berbahasa mahasiswa dalam berinteraksi dengan dosen di Universitas Ahmad Dahlan: analisis pragmatik. The 5TH Flurecol Proceeding, UAD, Yogyakarta, 557-571.

Creswell, J. W. (2010). Research design pendekatan kualitatif, kuantitatif, dan mixed. Yogyakarta: pustaka pelajar.

Diana, N. (2016). Pengaruh Teknologi Informasi dan Komunikasi terhadap Etika Berbahasa Mahasiswa. Jurnal Al Mabhats, 1(1), 134-147.

Gazalba, S. (1973). Sistematika filsafat. Bulan Bintang.

Gunawan, F. (2013). Wujud Kesantunan Berbahasa Mahasiswa Terhadap Dosen di STAIN Kendari: Kajian Sosiopragmatik. Jurnal Arbitrer, 1(1), 8-18.

Hudiarini, S. (2017). Penyertaan etika bagi masyarakat akademik di kalangan dunia pendidikan tinggi. Jurnal Moral Kemasyarakatan, 2(1), 1-13.

Isnanto, R. R. (2009). Buku ajar etika profesi.

Marenda, P. (2020). 6 Chat Mahasiswa ke Dosen Ini Bikin Emosi Sekaligus Geregetan. https://m.liputan6.com/hot/read/4349614/6-chat-mahasiswa-ke-dosen-ini-bikin-emosi-sekaligusgeregetan

Mislikhah, S. (2020). Kesantunan berbahasa. Ar-Raniry, International Journal of Islamic Studies, 1(2), 285-296.

Moleong, L J. (2004). Metodologi Penelitian Kualitatif. Bandung: PT.Remaja Rosdakarya,

Mulatsih, S. (2014). Ketidaksantunan berbahasa pada pesan singkat (SMS) Mahasiswa Ke Dosen.

Nikmah, N., Rahwani, N. R., \& Fitriani, F. (2018, December). Etika komunikasi mahasiswa kepada dosen (studi pada mahasiswa Akuntansi Politeknik Negeri Banjarmasin). In Proceeding of National Conference on Asbis (Vol. 3, pp. 365-372).

Simorangkir, O. P. (2003). Etika Bisnis, Jabatan, dan Perbankan. Jakarta: Rineka Cipta.

Soekanto, S. (2014). Sosiologi suatu pengantar. Rajawali Press.

Vesiano, Q. A. (2019, June). Peran Etika Budaya Jawa Dalam Membangun Karakter Anak Usia Dini. In Seminar Nasional Pendidikan 2015 (pp. 314-320).

Wartoyo, F. X. (2019). Etika Komunikasi Mahasiswa dan Dosen dalam Perspektif Akademis Revolusi 4.0. Waskita: Jurnal Pendidikan Nilai dan Pembangunan Karakter, 3(1), 39-47. 